\title{
Challenges and Opportunities of Mango Production and Marketing in Assosa Zone of Benishangul Gumuz Region: Evidence from Ethiopia
}

\author{
Regasa Dibaba ${ }^{1}$ Afework Hagos ${ }^{1}$ Adam Bekele $^{2}$ Dawit Alemu ${ }^{3}$ \\ 1.Ethiopian Institute of Agricultural Research/Assosa Research Center, P.O. Box 265, Assosa, Ethiopia \\ 2.Ethiopian Institute of Agricultural Research/Melkasa Research Center, Melkasa, Ethiopia \\ 3.Ethiopian Institute of Agricultural Research, P.O. Box 2003, Addis Ababa, Ethiopia
}

\begin{abstract}
In support of stimulating growth, economic development, food security and alleviating poverty in BenishangulGumuz region in particular mango fruits play an important role in an on-going or future fruit development plan. In spite of the importance of mango fruits in generating income for smallholders' farmers, challenges and opportunities in mango production and marketing have not yet studied. As a result a cross sectional data was collected from 150 mango producer farmers. Moreover, focus group discussions using pre-tested semi structured questionnaires and checklists respectively and it was supplemented by secondary data collected from different published and unpublished sources. As a result, it provides basic and relevant information on production trends; marketing and consumption, access to governmental institutions, micro-finance, and technology transfer of mango improved varieties of the smallholder farmers were identified. Hence, developmental endeavors should be work on the identified gaps that could milk the opportunities and fill skills and knowledge gaps of smallholder farmers so as to improve their livelihoods. In this arena, emphasis should be given to improve effective production and marketing of mango.
\end{abstract}

Keywords: Mango, challenges, opportunities, Benishangul Gumuz

DOI: $10.7176 / \mathrm{JMCR} / 53-01$

\section{Background And Justification}

Fresh tropical fruits are on winning ground in world markets (Anonymous, 2001). Lumpkin et al. (2005) also pointed out worldwide production of fruit and vegetable crops have grown faster than that of cereal crops. Moreover, figuratively, pineapple accounts for $44 \%$ of the total traded volume, followed by mangoes $(27 \%)$, avocados $(12 \%)$ and papayas $(7 \%)$. The main reason for increase in demand of tropical fruits is the growing familiarity of consumers with tropical fruits; their taste, nutritional value and cooking qualities (Yeshitla (2004) are among the others.

Ethiopia is agro-ecologically diverse and is suitable for growing temperate, sub-tropical or tropical fruits. For example, substantial areas in the south and south-western parts of the country receive sufficient rainfall to support fruits adapted to the respective climatic conditions. In addition, there are many rivers and streams which could be used to grow various horticultural crops. Despite this potential, however, production-market chore of fruits has remained immature in the country (Joosten, 2007) mainly due to traditional focus which was in favor of cereals. Serious lack of information and 'on and off' productions have also played their deterring role (Naamani, 2007). Realizing these gaps, lately however, the government of Ethiopia has launched enabling environment to encourage chain actors. As a result, the Ministry of Agriculture has elevated the horticulture subsector from a small section to a level of agency (World Bank, 2004; Joosten, 2007; Kahsay et al., 2008).

More than 47 thousand hectares of land is under fruit crops in Ethiopia. Bananas contributed about $60.56 \%$ of the fruit crop area followed by Mangoes that contributed $12.61 \%$ of the area. Nearly 3.5 million quintals of fruits was produced in the country. Bananas, papaya, mangoes and orange took up $55.32 \%, 12.53 \%, 12.78 \%$ and $8.35 \%$ of the fruit production, respectively (CSA, 2009). However, less than $2 \%$ of all the produce is exported (Joosten, 2007). These fruits are typically cultivated to supplement household income from their main crops.

In Ethiopia, the existing income generating capacity of fruits as compared to its immense potentials at the macro and micro level is not encouraging. According to Yilma (2009), the production potential of fruits is not widely and evenly distributed across the various regions of the country. The cultivation is also seasonal and the supply is scanty and volatile even in areas where irrigation is possible. The knowledge gap on fruit production techniques and processing technologies is wide. Also, knowledge of domestic consumers of the benefits of fruits is confined to very few varieties of fruits. Hence, domestic demand, with the exception of few widely known tropical fruits, is generally small and, various studies show that people generally consume fruits and vegetables on a daily basis, without considering them as basic. These factors have adversely affected the growth and expansion of the fruit sub-sector in Ethiopia.Part of this, Assosa zone is endowed with diverse natural resource and has the capacity to grow different annual and perennial crops. Moreover, fruit production in the area is mainly for market. Though mango is the major fruit in the area the production and marketing challenges and 
opportunities have yet not identified. Therefore, the study was done to identify challenges and opportunities on mango smallholders' commercialization in the study area

\section{Materials and Methods}

\subsection{Study area Description}

Assosa zone is one of the three zones found in Benishangul Gumuz Regional State in Western parts of Ethiopia. Furthermore, Assosa district is one of the districts found in Assosa zone with estimated land area of $2330 \mathrm{~km}^{2}$. The altitude range is 1300-1570 masl. Assosa district has a total 78 kebeles/villages, where 74 are rural and 4 are urban. The dominant ethnic groups are Berta (indigenous communities), Amhara (settlers) and Oromo; while Tigrean, Guraghie and others account for the minority groups.

\subsubsection{Sampling size and sampling procedure}

Assosa district is dominantly inhabited by Berta (the indigenous) and the settlers. These communities have their own long developed farming practices and livestock keeping, natural resource management (forestry and soil). Again, socio-economic resources like land holding and farming implements are different among the two communities. Depending on such criteria six villages/kebeles, three from indigenous and three from settlers were selected. The indigenous villages/kebeles are Ura, Baro and Kushmengel which are inhabited by Bertas' and the settlers are Amba 2, Amba 10 and Selga 23 which is inhabited by settlers since 1980 settlement program.

Results are $\bar{b}$ ased on $\bar{a}$ survey of $1 \overline{5} 0$ households and six villages/Kebele Associations (KAs) at Assosa district in 2011/12. Farming systems were stratified in to KAs and households were selected randomly based on the proportional to size sampling. Data related to all-weather road and nearest market from the settlement center were collected at community level. Indices of land fragmentation, market orientation and crop output market participation were computed using the Households quantity of mango sold to the market at the cropping season.

\subsubsection{Type of Data and Method of Data Collection}

The research reviewed and analyzed existing secondary data with emphasis on commercialization, commercial farming, trends in agricultural production, Mango marketing, Mango value chain analysis and other secondary data relevant for data analysis and gap identification. The secondary data is collected from all relevant organizations like mango Cooperatives, published and unpublished regional and district level documents.

Moreover, primary data were collected and generated using focus group discussion, key informant discussion, discussion with experts, and field observation methods and questionnaire based formal surveys with key informants and farmers so as to investigate and cross check the data collected from formal survey. To cross check the collected information is correct semi-structured checklists were prepared well-designed and pre-tested questionnaire is prepared and data about In addition household characteristics, social networks, household land ownerships and allocation, mango production trends, crop utilization and production, livestock ownership and utilization, crop sales (marketing), market access, off farm incomes, institutions (access to credit and saving, access to training, technology and information), risks and shocks, mango production constraints, mango marketing constraints, management practices and access to agricultural inputs and supply (agric-service) providers etc. was collected using household survey.

\subsection{Data Management and Analysis}

To achieve the stated objective, descriptive data analysis is employed to analyze the challenges and opportunities of mango production and marketing. Information and data, which collected were compiled, and analyzed using appropriate statistical methods. The quantitative and qualitative data was analyzed based on descriptive and narrative analysis technique, respectively. Interpretation of qualitative data and information was done by sorting out, ranking, grouping and triangulation. The quantitative data analysis was done using statistical software.

\section{Results and Discussions}

\subsection{Socio Economic Setting}

\subsubsection{Household composition and characteristics}

According to the survey results, table 1 below indicates that mean age of the sample household heads was 50.83 with standard deviation of 15.22 years. Even if the farmers in the area have lived for long period of time (41.77years/ both indigenous and settler communities) their mango growing experience is 22.95 years on average (See table 1 below). The mean of sampled household head stay in the area is by far higher than that of experience in mango growing experience. 
Table 1 Age, family size, year lived and mango growing experience of households

\begin{tabular}{lrrrr}
\hline Descriptions & Mean & Std. dev & Min & Max \\
\hline Gender of the households & 0.9 & 0.3 & 0 & 1 \\
Household family size & 7.13 & 3.78 & 2 & 22 \\
Labour availability of the HHs & 3.88 & 2.59 & 1 & 19 \\
Age & 50.83 & 15.22 & 19 & 85 \\
Year lived in the area in years & 41.77 & 17.06 & 5 & 85 \\
Mango growing Experience & 22.95 & 10.28 & 5 & 70 \\
\hline
\end{tabular}

Source: survey result, 2012

Household size increases domestic consumption requirements and renders households more risk averse. Hence, controlling for labor supply, larger households is expected to have lower market participation. Hence, family size in the study is defined as the number of individuals who resides in the respondent's household, including family members who are temporarily away from home. According to the survey results (table 1), the average family size and economically active members of the households is about 7.13 and 3.88 respectively. Hence, controlling dependency ratio, larger households is expected to contribute for labor supply during harvesting and transporting mango and it would enhance market participation. As shown in table 1, the average family size of the respondents is 7.12 persons which are nearest to the national average. The maximum family size is 22 for the sample while the minimum is two persons. The large size is attributed to the common observation that many men have more than one wife which is a common practice in a culture of polygamy. Polygamy is common in the area especially among the indigenous Muslim-Berta's. Moreover, according to the survey result, about $10 \%$ of the sampled households were female headed.

Literate households are expected to have better skills, and better access to information and ability to process information, and thus may be positively associated with market orientation and market participation. As indicated in table 2, among the sample farmers, the majority ( $48.0 \%$ ) were illiterate, while about $52 \%$ could able to read and write and considered as literate households. This shows the importance of exerting efforts to improve the educational status of the farmers in the future since this will have a direct relation to the knowledge and skill improvement to commercialize and support farmers to adopt new technologies regarding to mango production and marketing.

Table 2: Education status of sample household heads

\begin{tabular}{lll}
\hline Level of Education & Frequency & Percent \\
\hline None/Illiterates & 72 & 48.0 \\
Literate & 26 & 17.3 \\
Total & 150 & 100.0 \\
\hline
\end{tabular}

Source: Current survey results, 2012

\subsubsection{Households access and arrangement to institutions}

Institutions play a vital role in providing agricultural production and marketing services like access to market, market information system, microfinance for credit and saving services, seed (seedling) supply, extension services provided by development agents, cooperative and transportation facilities. Related with this, access to different institutional services might contribute commercialization of smallholder farmers. Hence, farmers nearest to main market, nearest to main road and seasonal roads, agricultural inputs both adequately and timely are expected to enhance their market participation.

As indicated in the table below, sample farmers walk on average $3.64 \mathrm{~km}$ to get the nearest market. Moreover, the respondents walk about $15.86 \mathrm{~km}$ to reach the nearest main market which is Assosa market. Consequently, the farmers pay around $12 \mathrm{Birr} / \mathrm{person}$ to get the main market so as to buy goods for household consumption and sell their produce. The households usually walk on average $5.46 \mathrm{~km}$ to access the source of mango seedling. Thus, there are no mango seedling sources like mango nursery at community level; however some households established nursery sites around river basin.

Table 3: Distance to access institutional factors in 2011/12 cropping season

\begin{tabular}{lcc}
\hline \multicolumn{1}{c}{ Descriptions } & Maximum & Mean \\
\hline Distance to the nearest village market $(\mathrm{km})$ & 22.00 & 3.64 \\
Distance to the nearest main market $(\mathrm{km})$ & 18.00 & 15.89 \\
Transport cost (Birr/person) & 18.00 & 11.79 \\
Distance to the nearest source of mango seed/seedling $(\mathrm{km})$ & 18.00 & 5.46 \\
Distance to the nearest source of farm chemicals $(\mathrm{km})$ & 18.00 & 7.28 \\
Distance to the nearest farmer cooperative $(\mathrm{km})$ & 18.00 & 5.84 \\
Distance to the nearest agricultural extension office $(\mathrm{km})$ & 18.00 & 1.32 \\
\hline
\end{tabular}

Source: Current survey result, 2012

Closely connected with input supply and use so as to increase production and productivity of smallholder 
farmers, access to institutions and input markets is necessary. Hence, households access agricultural inputs like fertilizers on average at $7.62 \mathrm{~km}$. The main source of fertilizer is the Regional Bureau of Agricultural Development via Woreda agricultural Bureau in collaboration with rural credit and saving microfinance's underwriting loans to farmers for the purchase of fertilizers. It is because as to markets failures, this lowers transaction costs that would be required for transport and communication costs. The transaction costs in smallholder agriculture arise essentially from lack of information, contact enforcement, and coordination. With the strategies and policies of Ethiopia especially in the agriculture sector smallholder farmers should get agricultural services like cooperatives and technical support from development agents. Thus, households access agricultural extension service and primary farmers cooperative on average at $1.32 \mathrm{~km}$ and $5.62 \mathrm{~km}$ regardless of the service they provide. Fruits including mangoes were the main source of immediate income generating of the farmers at Assosa Woreda. The trends in production is listed in the following table.

Table 4: Major fruits yield (Qt) and area covered in hectare of Assosa district (2006-2011)

\begin{tabular}{|c|c|c|c|c|c|c|c|c|c|c|}
\hline \multirow{3}{*}{ Fruit crops } & \multicolumn{10}{|c|}{ Years } \\
\hline & \multicolumn{2}{|c|}{$2006 / 07$} & \multicolumn{2}{|c|}{$2007 / 08$} & \multicolumn{2}{|c|}{$2008 / 09$} & \multicolumn{2}{|c|}{$2009 / 10$} & \multicolumn{2}{|c|}{$2010 / 11$} \\
\hline & Area & Yield & Area & Yield & Area & Yield & Area & Yield & Area & Yield \\
\hline Orange & 1 & 96 & 4.01 & 30.4 & 31 & 2356 & 0.62 & 523 & 0.62 & 1520 \\
\hline Banana & 15 & 200 & 103.1 & 8248 & 184 & 15280 & 11.7 & 3365 & 4.03 & 322.4 \\
\hline Lemon & 2 & 130 & 2.95 & 509.5 & 20 & 1400 & 1.59 & 674 & 0.5 & 350 \\
\hline Mango & 55 & 5775 & 161.6 & 16963 & 435 & 2600 & 10.3 & 35400 & 103 & 25500 \\
\hline Papaya & NA & NA & NA & NA & 10 & 2000 & 4.03 & 2845 & 40 & 8000 \\
\hline Avokado & NA & NA & NA & NA & 3 & 600 & & 112 & 11.67 & 2334 \\
\hline
\end{tabular}

Source: Assosa district Bureau of Agriculture \&Rural Development, $2011 \quad$ NA= Not Available

The above table shows that mango production trends at district level were increasing from year to year though the nature of the crop is biennial. Papaya production was also increased though the production data were not available for the years 2010 to 2011 .

\subsection{Propagation and Management Practices of Mango}

\subsubsection{Mango Regeneration and propagation}

According to the survey results below, there is a dramatic increase in average mango trees plantation and sold mangoes after intervention has been made in establishing farmer groups so as to improve marketing systems of mangoes. Hence, the households have around thirty productive mango trees on average.

Table 5 Number of productive mango trees and price of mango

\begin{tabular}{lll}
\hline Particulars & Maximum & Mean \\
\hline Mango average price(birr/kg) & 6.00 & 1.15 \\
No. of mango trees & 850 & 29.67 \\
\hline
\end{tabular}

Source: Survey results, 2012

Both indigenous and settler communities practice mango seedling raising and propagation methods. From the table below, about 90.7 percent of the households employed mango plantation, however only 9.3 percent of them regenerate mango by naturally growing mango seedlings. In addition to this, 74 percent of the households transplant mango seedlings, whereas 24 percent of them sow fruits direct on the farm and very few ( 2 percent) of them employed mango grafting practices to propagate mango trees.

Table 6: Regeneration practices and Propagation methods of the households

\begin{tabular}{|c|c|c|}
\hline Regeneration process & Frequency & Percent \\
\hline Planted & 136 & 90.7 \\
\hline Growing Naturally & 14 & 9.3 \\
\hline Transplanting & 111 & 74.0 \\
\hline Direct seeding/sowing on the farm & 36 & 24.0 \\
\hline Grafting & 3 & 2.0 \\
\hline Total & 150 & 100.0 \\
\hline
\end{tabular}

Source: Current survey result, 2012

\subsubsection{Mango management practices}

To increase production of mango, like any other plants it needs management practices. Mango production practices differ in both communities. Indigenous communities grow mango at backyards, river basin (irrigated) and as natural forest. The settlers however grow mango only at their farmstead. Due to different mango growing practices, wild fire is the major distractive problem of natural forests and mangoes grown at river basin and as a natural forests are victims of the same problem. Table below revealed that, about 90.7 percent of the sampled households practice fire control/fire breaks. Pests like termite are the major production constraints of the farmers, and 70.0 percent of them practice termite control mechanisms like flooding to the termite colonies so as to kill 
the queen and digging breaks.

Table 7: Rank of management practices of mango by the households

\begin{tabular}{|c|c|c|c|c|c|}
\hline \multirow{2}{*}{ Management Practices } & \multicolumn{2}{|c|}{ Frequency } & \multicolumn{2}{|c|}{ Percent } & \multirow{2}{*}{ Rank } \\
\hline & No & Yes & No & Yes & \\
\hline Weeding & 87 & 63 & 58 & 42 & $5^{\text {th }}$ \\
\hline Manure application & 85 & 63 & 56.7 & 43.3 & $4^{\text {th }}$ \\
\hline Pruning & 125 & 25 & 83.3 & 16.7 & $8^{\text {th }}$ \\
\hline Fire control & 14 & 136 & 9.3 & 90.7 & $1^{\text {st }}$ \\
\hline Termite control & 45 & 105 & 30.0 & 70.0 & $2^{\text {nd }}$ \\
\hline Pollarding & 119 & 31 & 79.3 & 20.7 & $7^{\text {th }}$ \\
\hline Protection of young fruit trees & 45 & 105 & 30.0 & 70.0 & $2^{\text {nd }}$ \\
\hline Other pests control & 115 & 35 & 76.7 & 23.3 & $6^{\text {th }}$ \\
\hline Fencing & 141 & 9 & 94.0 & 6.0 & $9^{\text {th }}$ \\
\hline Others(Chemical application) & 3 & 147 & 98.0 & 2.0 & $10^{\text {th }}$ \\
\hline
\end{tabular}

Source: Current survey result, 2012

About 70 percent of the households protect young mango fruits and trees. Other management practices like weeding, manure application, other pests' control, pollarding and fencing was practiced. Even though mango pests and diseases are among the key production challenges, major mango disease and pests are not yet identified and the households were not able to treat their crop. Thus, only 2 percent of the households used chemicals to protect pests and diseases. The main reason for inadequate use of pesticides and other farm chemicals is there is no recommended input to apply for the pests, fungal and bacterial diseases. Moreover, there is no farm input suppliers in the area and the sampled respondents could not access farm chemicals.

\subsection{Mango Production Trends}

Unlike other crops, mango is a biennial crop and gives most of the time good yield in two years intervals. This is due to lack of harvesting stick, smallholder farmers collect mango fruits by cutting the branch of mango. As a result, to initiate a shoot for flowering it takes one year and flowering will continue at the next cropping season. Moreover, the sampled respondents explained that there is an opportunity to give production in consecutive years if the collection of fruits is done properly without harming the branches of mango tree. To do this harvesting stick/fruit collecting technology is needed. The farmers use their indigenous knowledge to harvest fruits year by year by cutting the flower/deflowering of one side of mango trees. This is nothing, but to avoid fruiting so as to collect next season so that the shoots of mango tree do not injured.

The next table and graphs depicts the trends of mango production of the households over last consecutive years. The households produce more than 2.3 tons of fruits on average in 2007. There is a slight decrease in yield at 2008 due to the perennial nature of the crop and the yield is lowered to 1.7 tons per household. In 2009, the yield is relatively higher and up-and-down trends of the production of mango are typically observed. The below mentioned yield of mango represents only marketed mangoes, otherwise the farmers consume large tones of mangoes and the remaining huge amount of mangoes spoiled and consumed by animals due to marketing problems(lack of buyers) and very cheap price offered for the produce.

Table 8: Mango Production Trends/ over last five years

\begin{tabular}{ccc}
\hline Year & Maximum & Mean yield(Qt) \\
\hline $2007 / 06$ & 400.00 & 23.54 \\
$2008 / 09$ & 300.00 & 17.47 \\
$2009 / 10$ & 350.00 & 24.46 \\
$2010 / 11$ & 800.00 & 22.88 \\
$2011 / 12$ & 1200.00 & 49.87 \\
\hline
\end{tabular}

Source: Survey results, 2012

Currently, the smallholder farmers supply to the market about 5 tons on average. This is because of relatively fair price and primary farmers' cooperatives' establishment at Kebele level. While, cultivation of commercial hybrids varieties of mango could potentially grow the market, quality and price of mangoes. Hence, improvement the existing varieties of mango without affecting the juice quality, could also grow cottage industries (of mango suitable for agro-processors) for the sustainability by enhancing production and productivity. 


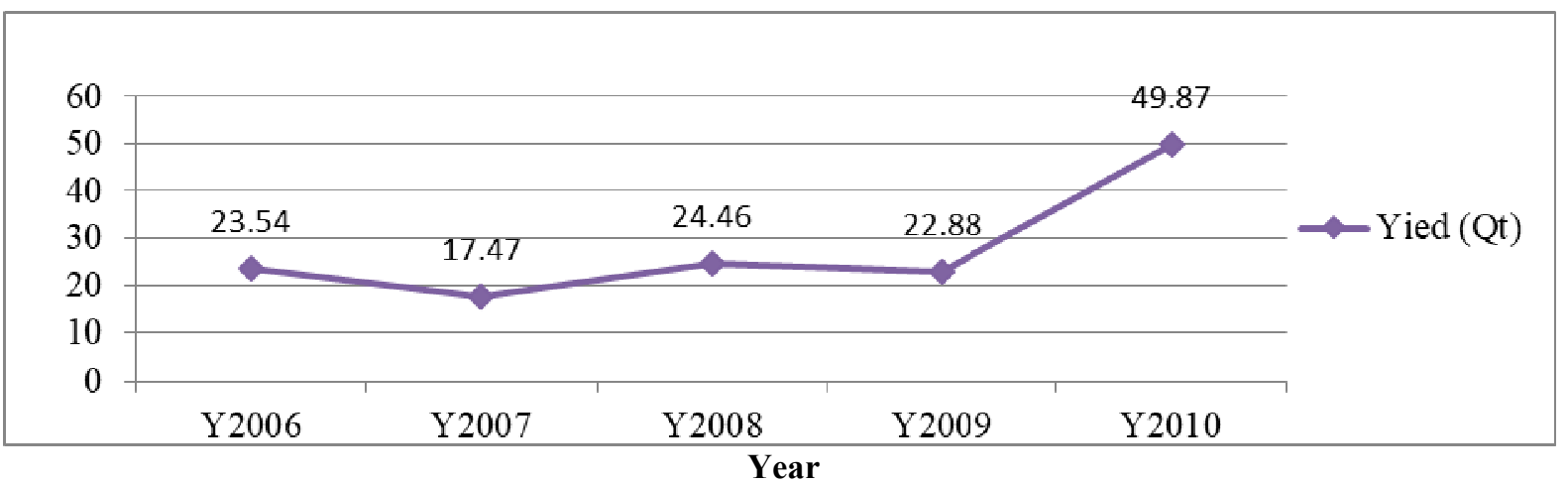

Figure 1: Graphical representation of mango yield for the last five years (2006/07-2010/11)

\subsubsection{Social networks and coherences of households}

Not only economic but also social capital of smallholder farmers is expected to enhance commercialization of smallholder farmers. Strong social bonds could minimize burdens in case of households' livelihood shocks and risks. The households' social network depends not only on the position of the households in the community, but also on the social life and approaches.

Table 9: Social networks of the sampled households

\begin{tabular}{lc}
\multicolumn{1}{c}{ Traders and brokers } & Mean \\
\hline Number of mango traders in this village who could buy mango & 1.12 \\
Number of mango traders Outside the village & 2.24 \\
No. of brokers & 2.70 \\
\hline
\end{tabular}

Source: Current survey results, 2012

Smallholder farmers usually trust traders in the village that could buy the mango produces. Because, in case if the traders took their mango produce, they would have their family and land of the traders as an insurance/guarantee. The number of traders/brokers that could buy mangoes within the village was on average 1.12 persons. However, the number of traders of mango outside their village is twice (2.24) than that of within the village and the number of brokers is also more than double than the households trust to buy their mango produce.

\subsubsection{Households access to information and technology transfer participation}

The table below indicates that, only 14 percent of the households were got information about new mango varieties and 86 percent of the households were not got any information or training on new mango varieties before January 2010. However, during 2010, 80 percent of the households was trained and access information on new mango varieties. Only 20 percent of the households were not got any training and information on the specified issue.

The major source of training on improved variety of mango was provided by NGOs (11.3 percent), agricultural experts usually from government extension service (8 percent) (experts at district and village levels), and 11.2 percent from farmer cooperative or groups and shared from their neighbors. On the same table below, about 28 percent of the households were accessed information and or training on field management of crops, but most of the households ( 72 percent) has no information on field management of crops before January 2010. About 24.7 percent of the HHs was trained and access information during 2010 on the specified issue.

Table 10: Training, knowledge and information source and status of the households

\section{Training type}

Information on New mango varieties

Field management of crops

Soil and water management

Irrigation

Output market and price

Input market prices

Collective action/Farmers organization

Livestock production

Family health

Family planning

Tree planting

General Agriculture

\begin{tabular}{cccc}
\multicolumn{3}{c}{ Before 2011 } & \multicolumn{2}{c}{ During 2011 } \\
\hline Yes (\%) & No (\%) & Yes (\%) & No (\%) \\
14 & 86 & 80 & 20 \\
28 & 72 & 24.7 & 75.3 \\
28.7 & 71.3 & 29.3 & 70.7 \\
23.3 & 76.7 & 25.3 & 74.7 \\
16.7 & 83.3 & 18 & 82 \\
16 & 84 & 14.7 & 85.3 \\
20 & 80 & 24.7 & 75.3 \\
19.3 & 80.7 & 20.7 & 79.3 \\
34.7 & 65.3 & 34.7 & 65.3 \\
35.3 & 64.7 & 35.3 & 64.7 \\
22.7 & 77.3 & 23.3 & 76.7 \\
22.7 & 77.3 & 21.3 & 78.7 \\
\hline
\end{tabular}

Source: Current Survey data results, 2012 
As indicated on the appendix table, 20,6.7 and 5.3 percent of the information on field management of crops was given by government extension services, NGOs and others farmers and research center, respectively. Generally, the above table (10) revealed that the households have limited access to information on soil and water management, irrigation, output and input markets and prices, collective action/farmer organization, livestock production, family health and planning, tree planting and general agriculture. The main source of information was government extension serves, research centers, other farmers and NGOs. The households accessed very limited information from TV, radio, farmer group cooperatives and private traders.

Those results show that government and NGOs made a little effort on knowledge and information transfer though the level of knowledge transfer remains at its infant stages. Hence, continues information and training is needed to fill knowledge and skill gap of smallholder farmers on the specified issues so as to transform the traditional farming system of the households to modern agriculture. Generally, mango cultivation in the area is characterized by poor cultivation and there are no input suppliers like improved seedlings, grafting etc. Hence, a low extension service in support to mango production is a major constraint.

The Table (11) below indicated source of seedling and about 23.3 percent of the households uses seedlings that grow at their field and any trees from the field. About 19.3 and 17.3 of the HHs use seedlings farmer to farmer seedling exchange and own farm selected trees depending on the mango quality according to the table below. From the same table 22 percent of the HHs inherited mango from their family. Very few farmers got mango seedling from government, NGOs, and other sources.

Table 11: Main Source of Mango Seed/Seedling

\begin{tabular}{|c|c|c|}
\hline Source of seedling & Frequency & Percent \\
\hline Any tree on-farm & 35 & 23.3 \\
\hline Own farm selected trees & 26 & 17.3 \\
\hline Local seed producers & 6 & 4.0 \\
\hline Agro-dealers & 2 & 1.3 \\
\hline Farmer to farmer seed exchanges & 29 & 19.3 \\
\hline Provided free by NGOs/Government & 9 & 6 \\
\hline Inherited from family & 33 & 22.0 \\
\hline Others & 10 & 6.7 \\
\hline Total & 150 & 100.0 \\
\hline
\end{tabular}

Source: Survey results, 2012

\subsection{Mango Marketing Environment}

According, James et al., (2008) on mango value chain indicated that most of mango fruits at Assosa are sold either through the larger market channels in Addis. The farm-gate channel mainly sells to traders (who sell on to Addis), consumers and small-retailers. The Assosa town (nearest main market) mainly sell to local consumers and small retailers-mainly sell to local consumers. Table 13 above revealed that about 74 percent of the households sold their fruit at the farm-gate with an average price of birr 1.15 per $\mathrm{kg}$.

Table 12: Mango average price and number of productive mango trees

\begin{tabular}{lccc}
\hline \multicolumn{1}{c}{ Description } & Observation & Maximum & Mean \\
\hline Mango average price (birr/kg) & 150 & 6.00 & 1.15 \\
No. of mango trees & 150 & 850 & 29.67 \\
\hline
\end{tabular}

Source: Survey results, 2012

Depending on the flowering time and varieties of mangos, most of them mature starting from March to May. With the availability of the fruits the price of mango fluctuates. Due to shortage of supply of mango and lack of competitors, mangos that mature early and late from march- to- May sold at higher price i.e. up to $6 \mathrm{Birr} / \mathrm{kg}$ though the degree of quality deterioration of the produce is sever during those times.

\subsubsection{Gender Issues and Mango Marketing}

According to James et al., (2008) large traders delivering in to Addis know which varieties and what grade of mango is suitable and this information is basic and strong position in the marketing chain. The astuteness of small numbers of traders has allowed them to vertically integrate their operations, capture a large proportion of the chain and stamp their dominance on the chain in oligopolistic fashion. This study also showed a complement results, i.e. more than half (i.e.53.3 percent) of the smallholders sold their produce to brokers and then pack them onto trucks which leave directly to Addis markets. Smallholder farmers do not perform picking, grading, packaging, bulking and transporting to Addis markets. In addition, 12 percent of the households sold mango fruits to farmer unions/ cooperative and about 8 percent of them sold it to urban mango traders. This shows that due to interventions made to enhance market options to smallholders, little efforts has been done to establish working cooperatives amongst growers. Thus, it actually contributed that the price of mango and coordination is little bit fair so as to compute traders and emerged farmer cooperatives. 
While focus group discussion, the smallholder farmers described that to enhance production and marketing of mango, Benishangul Gumuz regional state established mango unions. As a result, though production and productivity of other crops is stagnated by many factors, the union members save more than 40,000 ETB in two consecutive years after the establishment of the farmers' cooperative and unions on mango.

Associated with the road infrastructural expansion in the rural areas, the produce is sold at farm-gate and this improves females' participation in selling mango fruits though it is at the infant stage. As a result, 64 percent of the sampled household responded that males deal to sell mango produce. And 21 percent of the households females was sold mango and sometimes both men and women together accounted for 14 percent. This showed that women participation in mango marketing is encouraging.

Collection/harvesting of mango for consumption differ from collecting of fruits supplied to market. About 80.7 percent of the households replied that all family members harvest fruits for consumption, while 48.7 members of the households collect fruits supplied to market. About 16 and 47.3 percent of the household heads harvest fruits for home consumption and marketing, respectively. Consequently, women have little authority on the collecting of fruits to home consumption and marketing.

As it is discussed above, smallholder farmers do not perform picking, grading, packaging, bulking and transporting to Addis markets. However, those marketing functions could be easily done by women and add value on the produce and earn service margin on mango.

Table 13: Mango seller and gender participation

\begin{tabular}{lccc}
\hline & Gender & Frequency & Percent \\
\hline Female & & 32 & 21.3 \\
Male & & 96 & 64.0 \\
Both & & 22 & 14.7 \\
& Total & $\mathbf{1 5 0}$ & $\mathbf{1 0 0 . 0}$ \\
\hline
\end{tabular}

Source: Survey results, 2012

\subsubsection{Mango market access and infrastructures}

Mango market access is influenced by many factors, mainly infrastructural problems; those are associated with inadequate informatory structures. For example, standardized measures and grades for mango, effective price reporting, and transportation are among the bottle necks subjects to deterioration the quality of mango produce.

\subsubsection{Transportation}

Transportation problem can lead to quality deterioration of mango due to its perishability characters of the produce. Since lack of availability of mango processing plants at the nearest area and storage bottle necks are widely present the produce exposes to sunlight and related factors that affect the quality of mangoes collected as a result of transportation exposures of the produce to the environmental factors increases. As a result huge tones of mango fruits are rejected by the brokers and the damage effects lower the quality and smallholder farmers are subjected to sell their produce at lower price.

Table 14 Mango mood of transport

\begin{tabular}{lcc}
\hline \multicolumn{1}{c}{ Descriptions } & Frequency & Percent \\
\hline Did not transport & 117 & 78.0 \\
Hired Truck & 5 & 3.3 \\
Public transport & 7 & 4.7 \\
Donkey & 5 & 3.3 \\
Oxen/horse cart & 1 & .7 \\
back/head load & 6 & 4.0 \\
Others & 2 & 1.3 \\
Total $\quad 143$ & 95.3 \\
Not responded & 7 & 4.7 \\
\multicolumn{1}{c}{ Total } & $\mathbf{1 5 0}$ & $\mathbf{1 0 0 . 0}$ \\
\hline
\end{tabular}

Source: current survey result, 2012

One of the marketing functions of mango is transporting. This takes two phases of transportation activities, i.e. from the mango field/farmstead to the nearest mango loading place and from the loading place at farm-gate to Addis Ababa or nearest main market. As a result of farmers' sale mango at farm-gate- about 78.0 percent of the households does not transport mango. Whilst, about 4.7 percent of the households use public transport to sale their mango produce and 4 percent of them use back load to transport mango to the nearest main market. About 3.3 percent of them use hired trucks and donkey as a means of transportation.

\subsubsection{Storage}

There is no storage in the mango growing area. To maintain the quality of mango cold chain logistics is recommended. Due to lack of storage smallholder farmers are obligated to sell their produce only for three months. But, storage infrastructures like cold chain could help smallholders to ensure supply of quality mangoes 
and or at least they can minimize the incidence of huge tones of losses due to storage problems and maintain the quality of the produce.

\subsubsection{Processing Plants}

Despite the substantial amount of fruit that grown in Ethiopia, the fruit processing industry in the country is very weak. This is due to highly developed processing industries in other countries which are able to export in to countries like Ethiopia and sell the final product at low cost. Consequently, this remained entry barriers for domestically produced juice considering variety, quality, consistency and price of imports. Though research reports indicated that mango juice processing plant is a viable sector it remained at its infant stages.

Furthermore, the main marketing and production challenge of mango of the HHs in the growing area is lack of processing plants/agro-industries that could sustainably buy mangoes. And, also lack of technical knowledge in processing and low level of technical support of research institutions to develop appropriate technologies are key challenges in the study area.

\subsubsection{Market Information}

The study results revealed that there are underdeveloped market information and lack of knowledge/understanding on the incentive for improving productive capacity and quality of the HHs. Hence, 24 percent of the HHs did not get any market information to sell their produce. And 76 percent of them get market information discussion with other farmers $(40.3 \%)$, observation $(30.9 \%)$, and other combinations $(8 \%)$ i.e. from traders and unions and associations. This shows that smallholder farmers rely more on each other and via own observation market information to sell fruits.

Table 15: Access to market information before decided to sell mango

\begin{tabular}{cccc}
\hline Description & & Frequency & Percent \\
\hline & No & 36 & 24.0 \\
Access to market info & Yes & 114 & 76.0 \\
& Total & $\mathbf{1 5 0}$ & $\mathbf{1 0 0 . 0}$ \\
\hline
\end{tabular}

Source: Current survey result, 2012

In the area mobile service is available. However, since the market channel is dominated by brokers farmers do not use mobile to access market information on fruits. Further, if unions and associations are capacitated both financially and materially telephone, radio and television, and news peppers might be used as a source of market information for smallholder farmers.

Table 16 Means of access in market information

\begin{tabular}{|c|c|c|}
\hline $\begin{array}{r}\text { Source of market information } \\
\end{array}$ & Frequency & Percent \\
\hline Not accessed & 29 & 19.3 \\
\hline Observation & 46 & 30.7 \\
\hline Discussion & 60 & 40.0 \\
\hline Telephone & 1 & 0.7 \\
\hline Other combinations & 12 & 8.0 \\
\hline Others & 2 & 1.4 \\
\hline Total & 150 & 100 \\
\hline
\end{tabular}

Source: current survey results, 2012

Smallholder farmers faced market failures to sell their produce due to different challenges and constraints on the mango marketing system. These include poor harvest, lower price and lack of buyers. As a result, 54 percent of the households failed to sell their fruits due to lack of buyers. Not only due to poor harvest, but also lack of storage 38.7 percent of the households did not sold their produce. However, most of the HHs ( 80 percent) accepts any price set by the brokers' price to sell fruits. Only 20 percent fail to sell their produce as a result of poor price. During focus group discussion the informants replied that the marketing environment is dominated by brokers and illegal dealers and their produce is exposed to different external environmental factors. As a result, the brokers will deal to buy it at lower and discounted prices. Due to lack of market that emit the product at the nearest areas farmers usually agreed to sell fruits. The brokers have strong bonds and new small traders can't penetrate the bond and enter to the market.

Table 17: Reasons failure to sell mango produce

\begin{tabular}{lcc}
\hline \multirow{2}{*}{ Variables } & \multicolumn{2}{c}{ Failed To sell/Percent } \\
\cline { 2 - 3 } & Yes & No \\
\hline Lack of buyers & 54.0 & 46.0 \\
Poor Price & 20.0 & 80.0 \\
Poor Harvest & 38.7 & 61.3 \\
\hline
\end{tabular}

Source: current survey results, 2012

Depending to the survey results, on average 2.5 assemblers/brokers came to farm gate to buy fruits. On average 1 whole seller and 5.45 consumers and little number of farmer associations/unions came and bought 
fruits at farm-gate. The number of consumers bought their produce seems good but they buy few $\mathrm{kg}$ of fruits. Hence, HHs prefers to sell their fruit to wholesalers at the nearest main market (Assosa) for the sustainable supply of their produce.

Table 18: Number of buyers who came to buy mango at farm-gate in 2011/12

\begin{tabular}{lcc}
\multicolumn{1}{c}{ Types of market actors } & Maximum & Mean \\
\hline Assemblers or brokers & 15.00 & 2.5067 \\
Wholesalers & 20.00 & 1.0537 \\
Farmers Group Cooperatives & 5.00 & 0.2789 \\
Consumers & 500 & 5.47 \\
\hline
\end{tabular}

Source: Current survey results, 2012

Though consumers, wholesalers, assemblers/brokers and unions came to farm-gate due different reasons the HHs did not sell fruits to the market actors. In natural cases, smallholder farmers want to maximize their income from sales of their produces without any intention to its quality. Buyers want to buy quality produces at lower price. Especially commercial farmers want to sell the whole quantity they produced for market. Consequently, this leads to conflict in interest of value chain actors such as input suppliers, output traders, transporters, processors and growers/producers.

As a result of interest conflicts, smallholders especially fruits want to sell at farm-gate, but traders, and consumers want to buy at their nearest market to minimize transportation costs to buy the targeted commodity. Therefore, the HHs failed to sell to the different actors mainly lack of buyers, poor/unfair price, quality problems, quantity problems etc. Accordingly 56 percent of the HHs responded that due to availability of mango in every farmstead of smallholder farmers no consumers came to buy their fruits and 54 percent of the HHs reported that no farmer cooperatives in the area to buy their produce. Price offered by Unions/Associations is not a problem to the HHs, because they buy fruits at fair price than consumers, wholesalers and assemblers.

Table 19: Reason failure to sell mango at farm-gate during 2009/10 of the households

\begin{tabular}{lcccc}
\hline \multirow{2}{*}{$\begin{array}{c}\text { Reason failure to sell mango at } \\
\text { farm-gate }\end{array}$} & \multicolumn{4}{c}{ Market Actors } \\
\cline { 2 - 5 } & $\begin{array}{c}\text { Assemblers } \\
\text { (Brokers) }\end{array}$ & Wholesalers & $\begin{array}{c}\text { Farmers } \\
\text { cooperatives }\end{array}$ & Consumers \\
\hline No buyer has come & 10.0 & 18.7 & 54.0 & 56.0 \\
Price offered was low & 19.3 & 20.0 & 0 & 4.0 \\
Quality problem & 8.1 & 4 & 1.4 & 2.7 \\
Unable to meet desired quantity & 2.7 & 1.3 & 0 & 0 \\
Sold the whole to the market & 7.0 & 1.3 & 0 & 0 \\
Unable to buy all the fruits & - & 6.0 & 6.7 & 0 \\
\hline
\end{tabular}

Source: Current survey results, 2012

3.4.2.5. Education and Research

Adequate forestry and natural resource education, research and extension is needed to meet the demand for the challenges of managing natural resources on a sustainable manner. Strengthen education and research institutions in development of appropriate technologies suitable for increasing production and productivity of mango cultivation, grafting, top-working and management practices. Moreover, Strategies should developed for sustainable agro-forestry and natural resource management that will ensure food security and income for the smallholder farmers and long -term sustainability of the resource base upon which other development sectors depend. That is, linkage should be created among the core actors of mango value chains

\subsection{Land, Tree Tenure and Environmental Effects of Mango Cultivation}

Successful and long term agro forestry and mango tree planting strategies require land tenure systems. While smallholder farmers guaranteed and continues ownership, adoption of agro forestry and mango tree planting would be successful. Associated with the population growth, urbanization, wild fire and biological flowering of bamboo tree, government should introduce mango tree plantation so as to save the land and the environment. However, settlers are faced chronic farming land shortages and land for natural resource management and mango plantation shall redistributed from the communal land tenure so as the settlers could produce mango.

\subsubsection{Mango Production and Marketing Constraints}

Though there is huge potential in production and marketing of mango, it is also constrained by several factors. The production and marketing bottle necks includes availability and access to processing plants, reasonable mango prices, transportation problem, lack of knowledge in propagation, seedling problem etc. 
Table 20 Rank of key mango production and marketing challenges and constraints

\begin{tabular}{|c|c|c|c|c|c|}
\hline \multirow{2}{*}{ Type of production/marketing Constraints } & \multicolumn{2}{|c|}{ Frequency } & \multicolumn{2}{|c|}{ Percent } & \multirow{2}{*}{ Rank } \\
\hline & Yes & No & Yes & No & \\
\hline Lack of processing mango fruit in the area & 133 & 17 & 88.7 & 11.3 & 1 \\
\hline Mango transportation problem & 123 & 27 & 82.0 & 18.0 & 2 \\
\hline Mango preservation problem & 114 & 36 & 76.0 & 24 & 3 \\
\hline Lack of access to mango market and information & 112 & 38 & 74.7 & 25.3 & 4 \\
\hline Lack of reasonable mango prices & 110 & 40 & 73.3 & 26.7 & 5 \\
\hline Mango transportation cost & 86 & 64 & 57.3 & 42.7 & 6 \\
\hline Mango seedling quality problem & 69 & 81 & 54.0 & 46.0 & 7 \\
\hline Lack of knowledge on mango propagation & 67 & 83 & 44.7 & 55.3 & 8 \\
\hline Lack of seedling availability & 38 & 112 & 25.3 & 74.7 & 9 \\
\hline Lack of access to credit & 26 & 124 & 17.3 & 82.7 & 10 \\
\hline Price of improved mango seedlings & 24 & 126 & 16.0 & 84.0 & 11 \\
\hline \multicolumn{6}{|l|}{ Biological production constraints } \\
\hline Drought problems & 12 & 138 & 8 & 92.0 & 4 \\
\hline Flood problem & 3 & 147 & 2 & 98.0 & 5 \\
\hline Pests occurrence & 97 & 53 & 64.7 & 35.3 & 1 \\
\hline Disease & 66 & 84 & 44.0 & 56.0 & 2 \\
\hline Soil fertility problem & 38 & 112 & 25.3 & 74.5 & 3 \\
\hline
\end{tabular}

Source: Survey results, 2012

According to the survey results (table 20), the major production and marketing problems of mango fruits are ranked. Hence, 88.7 percent of the HHs ranked lack of processing mango fruits in the area and indicated as the key problem. Moreover, the households ranked mango transportation problem (truck) as their second major problem so as to sell their produce to mango cooperatives/unions then to Eth-fruit. Due to lack of transportation trucks in thousands of tones are deteriorated at the farm gate. About 76 percent of the HHs ranked mango preservation problem as their third main problems to take the advantage of the high quality and sweet juice of the Assosa mango.

The fourth major problem of the households was lack of access to mango market and information though access to market and information play a vital role to reduce transaction costs and enhance small-holders output market participation and 74.7 percent of the HHs was not got access on market and information of mango as the smallholders expectation is to sell their produce directly to traders without any intervention of brokers so as to share marginal profits that brokers actually take.

The households responded that since the brokers are price makers, smallholder farmers have not bargaining power to sell their produce. Consequently about 73.3 percent of the households was ranked lack of reasonable mango price is the fifth main constraint. Moreover, 57.3 percent of them responded that mango transportation cost is high to take their produce even to the nearest main market (Assosa market) and to sell mango fruits at fair price than the farm gate price though it is associated with mango transportation problem.

Mango seedling quality problem and lack of seedling availability are interrelated issues occurred more probably with lack of nursery site though farmers established very poor nursery site to grow mango seedlings around river areas. There are no commercial nurseries in the study area so as to offer improved mango varieties. However, world vision (NGOs) is trying to distribute to mango growers especially mango cooperative members limited numbers of improved mango varieties like apple mango, Kent and Tommy.

Lack of knowledge on mango propagation, lack of access to credit, and price of improved mango seedlings are not key constraints of the HHs but attributed to be the major factors that affect smallholder commercialization, that is to enhance mango market orientation and mango market participation. Amongst the biological mango production constraints, 64.7 of the households were faced pest problems. The major economic pests of mango listed by the households were ants, rat and termite. And also, disease was the second biological constraint followed by soil fertility problem. However, only 35 percent of the households was used pesticides.

\subsubsection{Opportunities for planting Mango trees}

- Land availability; particularly for indigenous community

- Interest in and willingness to plant improved mango varieties, top working etc.

- Adequate rainfall and ground water table availability

- Comfortable agro-ecology to grow mango trees

- Increasing support of extension services by development agents

- Willingness of the smallholder farmers to be trained on mango propagation techniques for improved fruit yield 


\section{Summary, Conclusion and Recommendations}

This study has tried to generate information on the constraints and opportunities of mango production and marketing at Benishangul Gumuz region. As a result, it provides basic and relevant information on production trends; marketing and consumption, access to governmental institutions, micro-finance institutions, and technology transfer of mango improved seedlings for the smallholder farmers were identified. Hence, developmental endeavors should be work on the identified gaps that could milk the opportunities and fill skills and knowledge gaps of small holder farmers so as to improve their livelihoods the following mitigation measures were suggested ;

O Farmers suggested provision of better planting materials and obtaining information on planting seasons

O Information on propagation, management practices of mango

- Empowering and establish mango cooperatives both in capital and materials like cold chain rooms

O Establishing nurseries and developing markets of mango fruits

- Mango processing plant should be established at the nearest area or linkage should be created to processors at the country

- Training on diseases and pests control of mango

- Training on processing mango juice and materials needed is crucial to take the advantage and add value at farm gate.

- To increase production and productivities and enhance food security, income, knowledge and skills of smallholder farmers' developmental endeavors should work and participate on the provision of improved crop varieties, input delivery, support research and development, improved livestock breeds , crop and livestock diseases control, crop management, sustainable natural resource management, soil and water conservations should be focused.

- Moreover, access to credit and saving institutions, FTC, capacity building and intervention on crops, livestock and natural resource managements should be strengthened.

- Research should be done in mango characterization urgently so as to use the opportunities of high juice quality of Assosa mangoes. Thus, top working and breeding works would be continued to produce suitable mango for agro industries and establish processing plants at the area at the long run.

- Adequate forestry and natural resource education, research and extension is needed to meet the demand for the challenges of managing natural resources on a sustainable manner. Hence, education and research institutions in development of appropriate technologies suitable for increasing production and productivity of mango cultivation, grafting, and top working and management practices should be strengthened.

- Smallholders have limited power in the mango value chain. Consequently, participating in marketing functions and value adding should be done by smallholder farmers especially by females in sorting, grading, processing bulking.

- Moreover, Strategies should developed for sustainable agro-forestry and natural resource management that will ensure food security and income for the smallholder farmers and long-term sustainability of the resource base upon which other development sectors depend. That is, linkage should be created among the core actors of mango value chains.

O To increase and enhance smallholder farmers farmer group cooperatives should be established and strengthened both in capital and logistically like cold room chains, and other necessary materials like harvesting stick, packaging materials for small-scale mango juice processors.

- Entrepreneurial training and advice should be given to smallholder farmers to move up the value chain for example processing mangoes to juice or providing pre-packaged fresh fruits for mango processors.

- Smallholder farmers, require not only marketing information but also financial and material assistances to help them to make a shift from subsistence production to the more market oriented production. 
Appendix 1. Source of training

\begin{tabular}{|c|c|c|c|}
\hline \multirow{2}{*}{ Training type } & \multicolumn{3}{|c|}{ Source of Training } \\
\hline & $1^{\text {st }}$ Source & $\mathbf{2}^{\text {nd }}$ & $3^{\text {rd }}$ Source \\
\hline $\begin{array}{l}\text { Information on New } \\
\text { mango varieties }\end{array}$ & $11.3 \%$ (NGOs) & $\begin{array}{l}8 \% \text { (Gov't extension } \\
\text { service) }\end{array}$ & 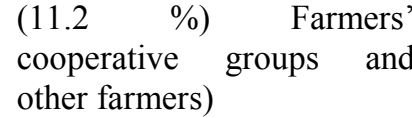 \\
\hline $\begin{array}{l}\text { Field management of } \\
\text { crops }\end{array}$ & $\begin{array}{l}20 \% \text { (Gov't extension } \\
\text { service) }\end{array}$ & $6.7 \%$ (NGOs) & $5.3 \%$ (Research Center) \\
\hline $\begin{array}{l}\text { Soil and water } \\
\text { management }\end{array}$ & $\begin{array}{l}25.3 \% \quad(\quad \text { Gov't } \\
\text { extension service }\end{array}$ & 3.0 (Other farmers) & $1 \%(\mathrm{RC}$ and $\mathrm{NGOs})$ \\
\hline Irrigation & $\begin{array}{l}20 \% \text { (Gov't extension } \\
\text { service) }\end{array}$ & $\begin{array}{l}4 \% \text { (farmers' cooperative } \\
\text { group) }\end{array}$ & $\begin{array}{l}\text { 1\% (Research center, Radio, } \\
\text { Television and NGO) }\end{array}$ \\
\hline $\begin{array}{l}\text { Output market and } \\
\text { price }\end{array}$ & $\begin{array}{l}12.7 \% \quad \text { (Gov't } \\
\text { extension service ) }\end{array}$ & $\begin{array}{l}4 \% \text { (NGOs and other } \\
\text { farmers) }\end{array}$ & $\begin{array}{l}1.3 \text { (Research center, TV\& } \\
\text { Private traders }\end{array}$ \\
\hline Input market prices & $\begin{array}{l}12.7 \quad \% \quad \text { (Gov't } \\
\text { extension service) }\end{array}$ & $\begin{array}{l}2 \% \text { (Radio, NGOs \& other } \\
\text { farmers ) }\end{array}$ & \\
\hline $\begin{array}{l}\text { Collective } \\
\text { action/Farmers } \\
\text { organization }\end{array}$ & $\begin{array}{l}19.3 \% \quad \text { (Gov't } \\
\text { extension service) }\end{array}$ & $\begin{array}{l}2 \% \text { (Farmers' cooperative } \\
\text { group) }\end{array}$ & $\begin{array}{l}2.7 \% \text { (NGOs, other farmers } \\
\& \text { Research center ) }\end{array}$ \\
\hline Livestock production & $\begin{array}{l}20.0 \quad \% \quad \text { (Gov't } \\
\text { extension service) }\end{array}$ & $\begin{array}{l}0.7 \quad \text { (Research center, } \\
\text { NGOs, Radio) }\end{array}$ & \\
\hline Family health & $\begin{array}{l}34.7 \quad \% \quad \text { (Gov't } \\
\text { extension service) }\end{array}$ & $4 \%,($ other farmers $)$ & $4 \%(\mathrm{NGOs})$ \\
\hline Family planning & $\begin{array}{l}34.7 \quad \% \quad \text { (Gov't } \\
\text { extension service) }\end{array}$ & $4 \%$ (other farmers) & $4 \%$ (NGOs) \\
\hline Tree planting & $\begin{array}{c}20.0 \% \text { (Gov’t extension } \\
\text { service) }\end{array}$ & $4.7 \%$ (other farmers) & 3.3 (NGOs) \\
\hline $\begin{array}{l}\text { General } \\
\text { Agriculture }\end{array}$ & $\begin{array}{c}18.8 \% \text { (Gov't extension } \\
\text { service) }\end{array}$ & $3.3 \%$ (NGOs) & $2.7 \%$ (Research center) \\
\hline
\end{tabular}

Source: Survey results, 2012 